原著

\title{
血管肉腫：4 例の細胞学的検討
}

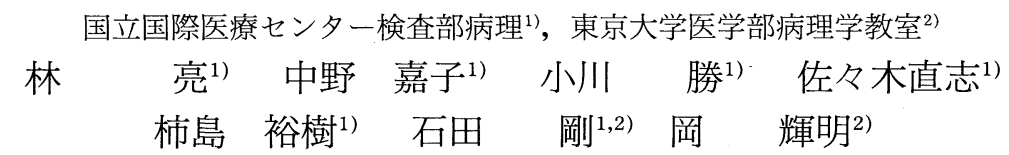

組織学的に血管肉腫と診断された 4 症例について細胞学的検討を行った。症例は 43 歳から 79 歳 にわたり，男性 3 例，女性 1 例，原発部位は頭頸部皮膚と心臓がそれぞれ 2 例であった。基本的細 胞所見として，ライトグリーン淡染性の紡鍾形ないし多稜形の細胞が，出血や炎症性背景の中に散 在性，あるいは中規模集塊を形成して観察された。腫瘍細胞の核は偏在傾向を示し，ときに多核の 腫瘍細胞も認められた。核のクロマチンは顆粒状を呈し，核小体が 1〜数個認められた。 2 列に並 ぶ配列をとる腫瘍細胞や，細胞質内に halo を伴う赤血球様物質を容れた腫瘍細胞が観察された。 免疫組織化学㐨よびレクチン化学的には，腫瘍細胞は第VIII因子関連抗原（F VIII RA），ビメンチン， Q-Bend-10, Ulex europeaus agglutinin I (UEA-I) 陽性であった.

血管肉腫は, その組織構築に病理学的診断根拠をおいているため, 細胞学的診断は困難な場合が 多い。しかし，腫瘍細胞が 2 列に並ぶ配列や，腫瘍細胞質内の halo を伴う赤血球様物質の存在は 血管肉腫を示唆する細胞学的特徵と判断された。ささらに F VIII RA, Q-Bend-10, UEA I など血管 内皮マーカーの免疫組織化学的，レクチン化学的検索を併用することにより，さらに正確な推定診 断が可能であると考えられた。

Key words : Soft tissue neoplasm- - Hemangiosarcoma-Cytology-Immunohistochemistry

\section{I. はじめに}

血管肉腫（hemangiosarcoma）は，頭頸部皮膚や

Hemangiosarcoma : Cytological study of four cases

Ryo HAYASHI ${ }^{1)}$, C.T., J.S.C., Yoshiko NAKANO ${ }^{1)}$, C.T., I. A.C., Masaru OGAWA ${ }^{1)}$, C.T., I.A.C., Naoshi SASAKI ${ }^{1)}$, C.T., J.S.C., Hiroki KAKISHIMA ${ }^{1)}$, C.T., I.A.C., Tsuyoshi ISHIDA $^{1,2)}$, M.D., Teruaki OKA ${ }^{2)}$, M.D.

${ }^{1)}$ Pathology Division, Clinical Laboratories, International Medical Center of Japan

${ }^{2)}$ Department of Pathology, Faculty of Medicine, University of Tokyo

論文別刷請求先 -162 東京都新宿区戸山 1 の 21 の 1 国立 国際医療センター検査部病理 林 亮

平成 6 年 5 月 23 日受付

平成 6 年 9 月 9 日受理
大腿部などの軟部組織に好発する比較的まれな悪性腫 瘍である，組織学的には，完全ないし不完全な血管腔 の形成を特徴とし，これを未熟な異型内皮細胞が被覆 する．また血管形成に乏しい低分化な部分では，紡錘 形細胞肉腫や未分化癌と区別できない組織像を呈す る1).

細胞学的に，血管肉腫細胞の細胞質は紡鍾形，線維 状，類円形，あるいはおたまじゃくし様など多彩で， 核は大小不同があり，多核細胞も認められる 瘍細胞の出現様式は, 孤立散在性, あるいは上皮様結 合を示す小規模集塊であり ${ }^{2,4,5,7,8)}$ ，ときに血管腔様構 造も認められるとされている5,6,9). また細胞質内に赤 血球の封入像や貪食像も観察される ${ }^{2,4 \sim 9)}$. このように 血管肉腫の細胞所見はきわめて多彩であり, 診断根拠 になる特徴的な細胞像には欠ると考えられている。こ 
のため血管肉腫の細胞学的推定診断は難かしいとされ ている ${ }^{2,5 \sim 7)}$. 今回われわれは血管肉腫の 4 剖検例にお いてその細胞学的検討を行い, 若干の知見を得たので 報告する。

\section{II. 症例}

症例 $1: 78$ 歳, 女性

原発部位：右額部皮膚

現病歴：昭和 63 年 3 月，右額部に出血斑様の皮疹 が出現し，同年 7 月，国立病院医療センター皮膚科を 受診した. 生検の結果, 血管肉腫と診断され入院とな った。同年 9 月, 胸水貯留し胸水中に悪性細胞が確認 された。同年 12 月, 腫瘍浸潤による胸水貯留, さら に気胸を併発し，呼吸不全により死亡した。

症例 $2: 58$ 歳, 男性

原発部位：右心房

現病歴：平成元年 1 月，全身倦怠感，不整脈を主訴 に他院を受診し軽度の心拡大を指摘された。同年 3 月, 心窩部から頸部にわたる疼痛, 悪心, 嘔吐が出現 し, 全身倦忠感, 食欲不振も増強したため当院を受診 した，胸部単純レントゲン上心陰影の拡大を，また心 電図上で ST 上昇を認め, 心膜炎の疑いにて入院とな った。 心囊穿刺にて，血性心囊液が得られ，その細胞 診にて異型細胞が多数認められた。同年 4 月, 心膜切 開術が施行され，組織学的に血管肉腫と診断された。 同年 5 月, 腫瘍の全身転移および播種性血管内凝固症 候群のため死亡した。

症例 $3: 79$ 歳, 男性

原発部位：左前頭部皮膚

現病歴：昭和 52 年, 左前頭部に出血斑様の皮疹が 出現した. 昭和 60 年 10 月, 当院にて生検が施行さ れ，血管肉腫と診断された。同年 11 月，頭部皮膚腫 瘍切除術が行われたが, 昭和 61 年, 前頭部に再発が 認められ, 昭和 62 年 7 月には, 腫瘍は左顎下部にま で拡がった。同年 8 月, 左耳下腺部腫瘍切除, 同年 11 月，前頭部皮下腫瘍切除を行うも，平成元年 8 月， 腫瘍の局所再発および全身転移のため死亡した。

症例 $4: 43$ 歳, 男性

原発部位：右心房

現病歴：平成 3 年 5 月, 感冒様症状が出現し, 次第 に悪化した。同年 12 月，患者は咳と発熱のため他院 に入院し右心房腫瘍と右心房冠動脈瘻の診断にて手術 が行われた。腫瘍の組織学的検索にて血管肉腫と診断
表 1 症例および検索材料

\begin{tabular}{|c|c|c|c|c|}
\hline 症例 & 年齢 & 性別 & 原発部位 & 細胞診検索材料 \\
\hline 1 & 78 & 女 & 右額部皮膚 & $\begin{array}{l}\text { 胸水 } \\
\text { 剖検時腫瘍捺印（皮膚） }\end{array}$ \\
\hline 2 & 58 & 男 & 右心房 & $\begin{array}{l}\text { 心囊液 } \\
\text { 剖検時腫瘍捺印（心, 肝) }\end{array}$ \\
\hline 3 & 79 & 男 & 左前頭部皮膚 & $\begin{array}{l}\text { 手術時腫瘍择印（耳下腺） } \\
\text { 剖検時腫掦捺印（皮膚） }\end{array}$ \\
\hline 4 & 43 & 男 & 右心房 & $\begin{array}{l}\text { 剖検時胸水 } \\
\text { 剖検時腫瘍择印 (心, 肝, 肺) }\end{array}$ \\
\hline
\end{tabular}

された。画像上，肺および肝臓に転移が認められたた め, 平成 4 年 1 月, 当院に入院した. 化学療法が施行 されたが, 同年 3 月, 全身衰弱のため死亡した。

\section{III. 材料と方法}

材料：細胞学的検索には, 穿刺時および剖検時に得 られた体腔液，および腫瘍捺印標本を用いた（表 1 ）。

方法：細胞標本に対してパパニコロー染色，ライト ギムザ染色, PAS染色, アルシアンブルー染色 （pH 2.5）およびベルリンブルー染色をそれぞれ行っ た. 症例 4 ではビメンチン (Nichirei, 原液), 第VIII 因子関連抗原 (F VIII RA ; DAKO，200 倍希釈)，QBend-10 (NOVOCASTRA，50 倍希釈)，ケラチン (KL-1; Immunotech, 100 倍希釈), 上皮膜抗原 (EMA；DAKO，100 倍希釈)，デスミン (Clone 9； ICN, 20 倍希釈), S-100 タンパク (DAKO, 400 倍 希釈), Ulex europeaus agglutinin I (UEA-I ; コ スモバイオ，100 倍希釈）に対する各抗体を用いて, avidin-biotin-peroxidase complex (ABC) 法にて 免疫染色を行った。なお UEA-I の染色は直接法に て行った。

全例のホルマリン固定, パラフィン包埋組織切片を 用いて, hematoxylin-eosin (H-E) 染色標本を新た に作成し組織学的に観察するとともに，これらの腫瘍 組織から得られた捺印標本と組織標本とを比較し, 細 胞学的所見を再検討した. また上記抗体を用いた免疫 染色も同様に行った.

\section{IV. 結 果}

\section{1. 細胞所見}

4 例とも基本的にはほぼ同様の細胞所見を示した。 
表 2 血管肉腫の免疫組織化学的結果のまとめ

\begin{tabular}{lcccc}
\hline \hline & 症例 1 & 症例 2 & 症例 3 & 症例 4 \\
\hline F-VIII RA & + & - & + & $+(+)$ \\
Q-Bend-10 & + & + & + & $+(+)$ \\
ビメンチン & + & + & + & $+(+)$ \\
ケラチン (KL-1) & - & - & - & $-(-)$ \\
EMA & - & - & - & $-(-)$ \\
デスミン & - & - & - & $-(-)$ \\
S-100タンパク & - & - & - & $-(-)$ \\
UEA-1 & ND & ND & ND & ND (+) \\
\hline
\end{tabular}

F VIII RA：第VIII因子関連抗原, EMA : 上皮膜抗原, UEA-I： Ulex europeaus agglutinin I, + : 陽性, 一 : 陰性, ND：検 索せず

（）内は捺印標本による免疫細胞化学的結果

出血や炎症性滲出物を背景として, 腫瘍細胞が孤立散 在性や中規模集塊で出現していた。腫瘍細胞の細胞質 はライトグリーン淡染性で比較的薄く, 紡錘形ないし 線維状，多稜形，類円形，あるいはおたまじゃくし様 など多彩な形態を呈していた（写真 1 )。核は偏在傾 向を示し，クロマチンは顆粒状で核小体は 1 個から数 個認められた。症例 2 および 4 では, 腫瘍細胞が 2 列 に並ぶ配列がしばしば観察された（写真 $2 ， 3 ）$. 細胞 質内に halo を伴う赤血球様物質を容れた腫瘍細胞が, 少数ながら全例において観察された（写真 3，4）。楕 円形で異型の強い細胞も散見され，ときに多核の腫瘍 細胞も認められた。体腔液塗抹標本でも捺印標本とほ ぼ同様の細胞像が認められたが，体腔液中では類円型 の細胞が比較的多く観察された（写真 5 )。また症例 1 の胸水では, 奇怪な形の異型巨細胞も観察された. 腫瘍細胞の細胞質はアルシアンブルーおよび PAS 染 色陰性であった。また, PAS 染色陽性の樹枝状構造 が腫瘍細胞集塊中に認められ，この構造周囲に腫瘍細 胞が絡み付いている所見が得られ，特徵的な構造とみ なされたがこの所見は 1 例のみであった. ベルリンブ ルー陽性のへモジデリン顆粒を貪食したマクロファー ジが存在する腫瘍細胞集塊も散在していた。

\section{2. 組織所見}

組織学的には, 類円形ないし紡錘形腫瘍細胞が不規 則に吻合する血管腔を形成して増生していた（写真 6 ). 血管腔の形成に乏しく, 腫瘍細胞が充実性に増 生する部分も観察された (写真 7 ). 皮膚原発の症例 においては, 腫瘍細胞は真皮と皮下組織内に境界不明 瞭に増生し, 膠原線維束間に分け入るように浸潤して いた。転移巣においてもほほ同様の組織像が認められ た. 組織学的には血管肉腫と診断された。

\section{3. 免疫組織化学的所見}

ビメンチン，Q-Bend-10 は全例に，F VIII RA は 4 例中 3 例で陽性を示した.ケラチン, EMA，デスミ ン, S-100 タンパクは全例陰性であった。 また, 症例 4 の捺印標本では, ビメンチン, Q-Bend-10, F VIII RA，UEA-I が腫瘍細胞に陽性で（写真 $8 \mathrm{a}, \mathrm{b})$ ，そ の他のマーカーは陰性であった（表 2 ）。

\section{V. 考察}

血管肉腫の細胞所見として, 出血性背景に腫瘍細胞 が，孤立散在性ないし小規模集塊やシート状集塊，あ るいは毛細血管様構造, 腺管様構造, ロゼット様構造 を示して出現することが報告されている ${ }^{2,4 \sim 9)}$. また腫 瘍細胞の細胞質はライトグリーン淡染性で, その形態 は紡鍾形ないし線維状, 多稜形やおたまじゃくし様な どと多彩であり, 胞体に赤血球の封入像や貪食, 空胞 形成が認められることがあると報告されている2 9). 核は類円形で比較的大きく, 偏在傾向を示し, 核膜は 均等に肥厚しており, クロマチンは顆粒状でその量は 比較的少なく, 核小体は明瞭で大きい.また末分化な 細胞では強い異型を示す核も認められる ${ }^{2 \sim 8)}$.これら の従来から指摘されていた細胞学的所見は, 自験例に おいてもほぼ同様に観察された。

今回の検討では, 上記の細胞学的所見に加え, 集塊 中に 2 列に並ぶ配列をとる腫瘍細胞が観察された.こ れは血管肉腫の組織レベルでの血管腔形成が, 細胞像 に反映していると考えられ，血管肉腫の細胞診断上有 用な所見であると考えられた。また細胞質内に halo を伴う赤血球様物質を容れた腫瘍細胞が認められた。 これは, 通常の赤血球頜食像と若干異なっており, そ の真の成因は不明であるが，標本作製上のアーチファ クトとは考えにくい. 細胞レベルでの血管腔形成を反 映している可能性もあり, 細胞診断上重要な所見であ ると考えられ, 今後さらに症例を重ね検討する必要が あると思われた。

今回検討した 4 症例では, 腫瘍細胞の出現様式や細 胞形態からでも癌腫との鑑別は比較的容易であった。 組織学的には, 血管肉腫は転移性腺癌と鑑別を要する ことがあり，このような場合，細胞診が鑑別診断上有 用であると考えられた。一方，紡錘形ないし線維状の 細胞が出現する肉腫, たとえば平滑筋肉腫や悪性線維 性組織球腫などと血管肉腫との細胞像のみからの鑑別 は実際には困難なことも多いと考えられるため, 上記 
の細胞学的特徵を見出すとともに臨床情報の十分な把 握が血管肉腫を積極的に推定するためには必要不可欠 と考えられた。

山田ら $\left.{ }^{6}\right)$ は, 組織学的に悪性血管内皮腫, カポシ肉 腫, 悪性血管周皮腫と診断された症例を総括して血管 肉腫として細胞所見を報告している。そして, 細胞学 的にこれら腫瘍の腫瘍細胞は，内皮細胞由来の異型細 胞 (内皮細胞型) と紡鍾状ないし線維状の異型細胞 （血管周皮細胞型）に大別されるとしている。しかし， 悪性血管内皮腫（今回われわれの検討した血管肉腫に 相当), カポシ肉腫, おょび悪性血管周皮腫はそれぞ れ別の疾患単位とされており，これらを一括して細胞 所見を論じることはできず，それぞれの疾患を比較し ながら各疾患ごとに細胞所見を再検討する必要がある と考えられた。山田らの報告している紡鍾状ないし線 維状の異型細胞が多く出現した腫瘍は悪性血管周皮腫 の症例と考えられるが，今回われわれの検討した血管 肉腫においても，紡鍾形ないし線維状の腫瘍細胞が目 立ち, 必ずしも悪性血管周皮腫の特徵とは思われなか った。このことは血管肉腫（悪性血管内皮腫）におい ても組織学的にしばしば紡錘形細胞肉腫像を呈する部 分があることと矛盾しないと考えられた。

光学顕微鏡的細胞レベルでその特徵的分化像がとら えられる非上皮性悪性腫瘍, たとえば横紋筋肉腫細胞 の横紋や悪性黒色腫のメラニン顆粒などとは異なり, 血管内皮細胞には電子顕微鏡的に Weibel-Palade 小 体という特徵的構造物があるものの, 光学䫓微鏡的に みることのできる，このような特徵的構造物がない. このような細胞レベルでの分化像の欠如が，血管肉腫 をはじめ, 細胞学的特徵に乏しい種々の非上皮性悪性 腫瘍の細胞診断を困難にしている1つの大きな要因と 考えられる. 今後組織像との対比を含めさらに検討す べき課題と考えられた。

免疫組織化学的に, 腫瘍細胞は血管内皮細胞のマー カーとされている F VIII RA に 4 例中 3 例で陽性であ った。また別の血管内皮細胞マーカーである Q-Bend $-10^{10)}$ ，およびビメンチンは全例で陽性であった。 ケ ラチン，デスミン，EMA，S-100 タンパクは全例で 陰性であったＦ VIII RA は特異性の高いマーカーとさ れており，陽性であれば血管内皮系の腫瘍であると考 えられる。一方, Q-Bend-10 はほかの軟部腫瘍でも 陽性を示すことがあるが，従来のマーカーとほぼ同様 に血管内皮系腫瘍での陽性率は高いとされている ${ }^{10)}$. また，自験例において全例陽性を示したことからもほ
かのマーカーと併用することにより，血管肉腫の診断 上有用なマーカーと考えられた。ビメンチンは特異性 に乏しくほかの間葉組織や低分化な癌においてもしば しば陽性となることが知られており，ビメンチン陽性 であることのみから血管肉腫と診断することはできな いが，ビメンチンが陰性であった場合には血管肉腫で ある可能性は考えにくく，その意味で有用なマーカー であると考えられた。症例 4 の捺印標本を用いた免疫 細胞化学的検索では，腫崵細胞はＦＶIII RA，Q-Bend -10, ビメンチンに陽性で，ケラチン，デスミン， EMA，S-100タンパクは陰性であった。また，レク チン化学的検索では, UEA-I が陽性を示し, 血管肉 腫を支持する結果が得られた。一般に穿刺吸引細胞診 では, 組織標本と違い, 通常は免疫細胞化学的検索を 行うほどの十分量の細胞診標本が得られないことも多 いが，細胞が十分採取されれば，これらのマーカー検 索を積極的に行い，より正確な推定診断をする必要が あると考えられた。

本論文の要旨は第 33 回日本臨床細胞学会総会（於福岡）にて 発表した.

\section{Summary}

A cytological study of four cases of hemangiosarcoma of the craniofacial skin and heart was performed.

The age of the patients ranged from 43 to 79 years. Three were males, and one was female.

Cytologically, the tumor cells were scattered and/or formed medium-sized clusters. Spindle-shaped and polygonal atypical cells were identified against a hemorrhagic and/or inflammatory background. The nucleus of the tumor cells was eccentrically located. The chromatin pattern was granular, and the nucleoli were prominent. Multinucleated tumor cells were occasionally observed. The two-cell-thick parallel arrangement of the tumor cells was observed in two of our four cases. In all of the cases, intracytoplasmic erythrocyte-like inclusions with halos were seen in the tumor cells. Immunohistochemically, the tumor cells were positive for Factor VIII-related antigen, Q-Bend-10, vimentin, and Ulex europeaus agglutinin I .

Hemangiosarcomas are usually diagnosed on the basis of their histological structure, such as vascular-channel formation. Thus, cytological diagnosis may be difficult in many cases. The two-cell-thick parallel arrangement of the tumor cells and intracytoplasmic erythrocyte-like inclusions, 
however, appeared to be pathognomouic cytological findings of hemangiosarcoma. Immunohistochemical studies using endothelial markers are also useful in differential diagnosis cytologically.

\section{文献}

1）石川栄世：血管肉腫，飯島宗一・他編，現代病理学大 系, 第 20 巻 軟部腫瘍, pp. 214 222, 中山書店, 東京, 1992.

2) Abele, J.S., Miller, T. : Cytology of well-differentiated and poorly differentiated hemangiosarcoma in fine needle aspirates, Acta Cytol., $26: 341 \sim 348,1982$.

3) Masin, M., Masin, F. : Cytology of angiosarcoma of the breast : A case report, Acta Cytol., $22: 162 \sim 164$, 1978.

4) Nguyen, G-K, McHattie, J.D., Jeannot, A. : Cytomorphologic aspects of hepatic angiosarcoma, Acta
Cytol., $26:$ 527 531, 1982.

5）杉江茂幸・他：血管肉腫の 2 例, 日臨細胞誌，30：564～ 570, 1991.

6）山田 喬-他：血管肉腫の細胞診一 11 例の分析一, 日臨 細胞誌, $22 ： 202 \sim 208,1983$.

7) Gaba, A.R., Fine, G., Raju, U.B. : Malignant angioendothelioma : Cytologic, histologic and ultrastructural findings, Acta Cytol., $27: 76 \sim 80,1983$.

8) Jayaram, G. : Cytology of hemangioendothelioma, Acta Cytol., 28:153 156, 1984.

9) Jayaram, G., Kapoor, R., Saha, M.M. : Hemangioendothelioma: Cytologic appearances in two cases presenting with multiple soft tissue and bone lesions, Acta Cytol., 31: 497 501, 1987.

10) Ramani, P., Bradley, N.J., Fletcher, C.D.M. : QBEnd/ 10 , a new monoclonal antibody to endothelium: assessment of its diagnostic utility in paraffin sections, Histopathology, $17: 237 \sim 242,1990$.

\section{写真説明}

写真 1 炎症性滲出物を背景におたまじゃくし様など多彩な形態を示す腫瘍細胞（Pap. 染色, $\times 40)$

写真 22 列に並ぶ配列を示す腫瘍細胞 (Pap. 染色, $\times 40)$

写真 3 細胞集塊中に, 赤血球様物質を容れた腫瘍細胞が認められ (矢頭), また下方で は, 紡鍾形異型細胞が 2 列に並ぶ配列をとっている（Pap. 染色， $\times 40 ）$

写真 4 Halo を伴う赤血球様物質を容れた腫瑒細胞 (Pap. 染色, $\times 100)$

写真 5 胸水中に観察された類円型腫瘍細胞集団 $(P a p$. 染色, $\times 40)$

写真 6 組織学的所見. 腫瘍は不規則に吻合する血管腔を形成して増生している（H-E 染色, $\times 20)$

写真 7 組織学的所見. 腫場は充実性に増殖し, 血管腔の形成は, この部分ではほとんど 認められない $(\mathrm{H}-\mathrm{E}$ 染色, $\times 40)$

写真 8 a : Q-Bend-10 陽性所見 $(A B C$ 法, $\times 40)$

b : F VIII RA 陽性所見 (ABC 法, $\times 40)$ 


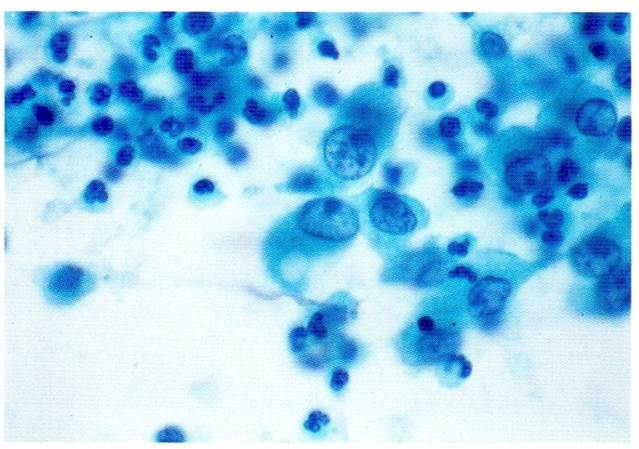

写真 1

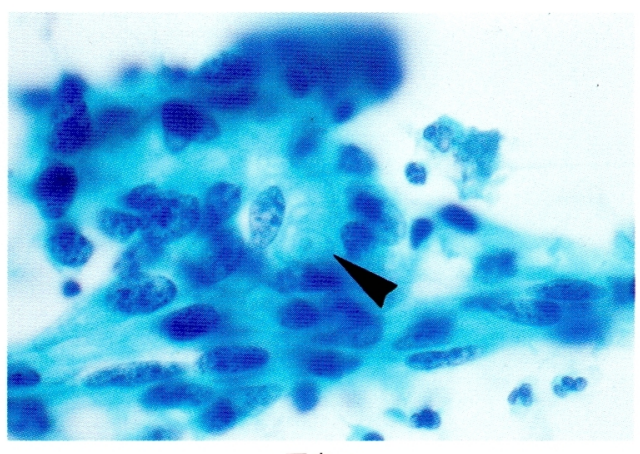

写真 3

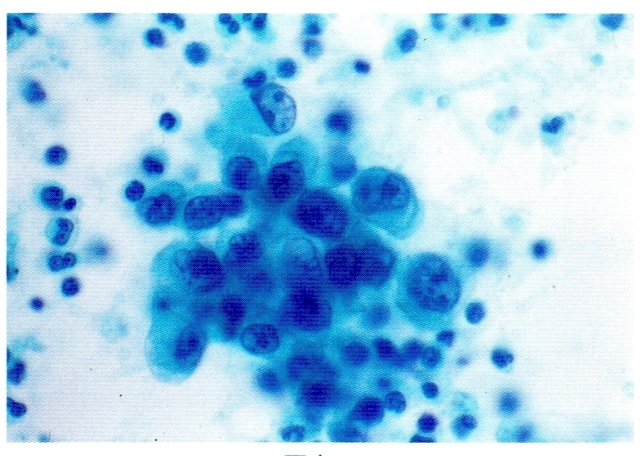

写真 5

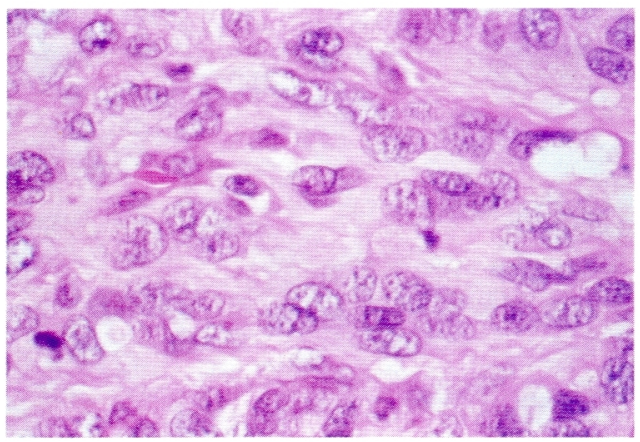

写真 7

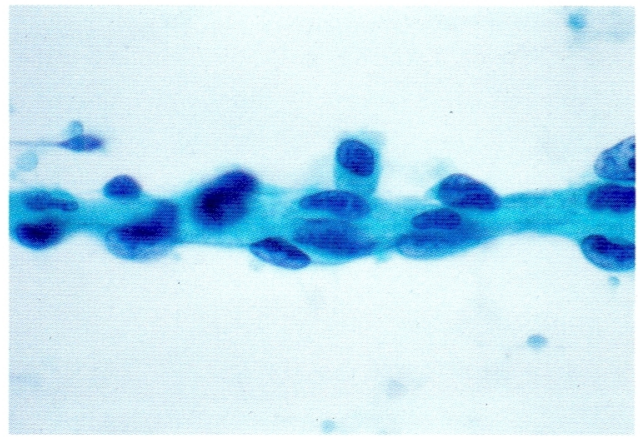

写真 2

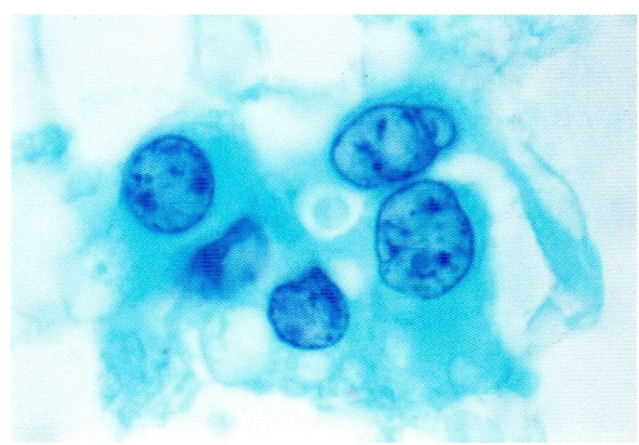

写真 4
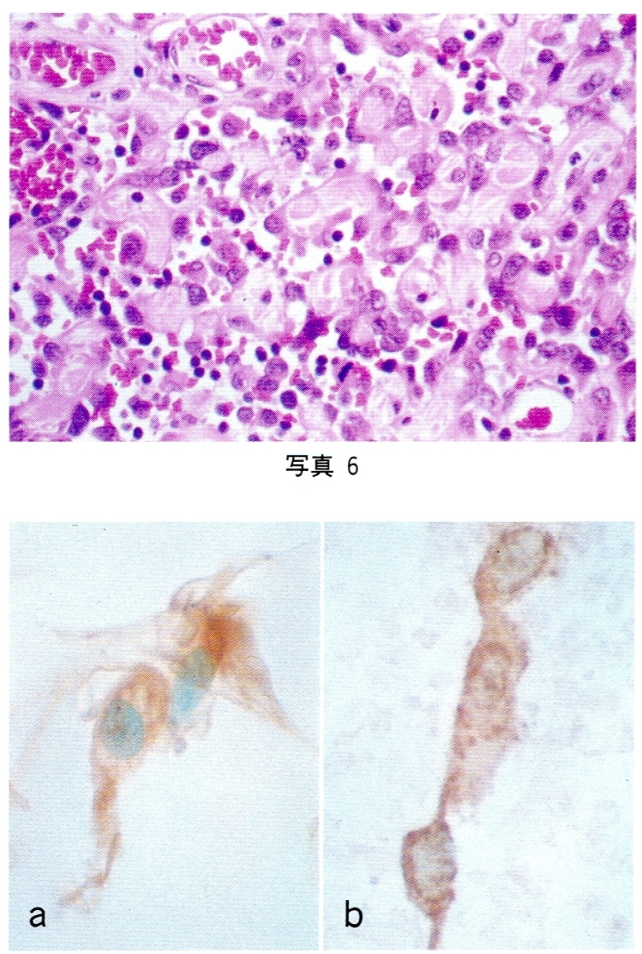

写真 8 